Jurnal Indonesia Sosial Teknologi: p-ISSN: 2723 - 6609

e-ISSN : 2745-5254

Vol. 2, No. 9 September 2021

\title{
AKUNTABILITAS PENGELOLAAN ANGGARAN PENDAPATAN DAN BELANJA DESA (APBDES) DI DESA MANGKONJAYA KECAMATAN BOJONGGAMBIR KABUPATEN TASIKMALAYA
}

\author{
Deni Nurcahya \\ STISIP Tasikmalaya \\ Email: deninurcahya33@gmail.com
}

\begin{abstract}
Abstrak
Akuntabilitas pengelolaan (APBDes) Desa Mangkonjaya masi memiliki permasalahan diantaranya, Kurang akuntabilitas terhadap pertanggungjawaban dari pihak pengelola Anggaran Pendapatan dan Belanja Desa (APBDes) yaitu adanya anggaran yang dikeluarkan bukan untuk peruntukannya, Kurang efektif dan efesiens dalam pengelolaan Anggaran Pendapatan dan Belanja Desa (APBDes), Kebijakan pelaksanaan Anggaran Pendapatan dan Belanja Desa (APBDes) kurang tepat terhadap pelaksaan dokumen sebelumnya yaitu RKPDes dan RPJMDes. Tujuan penelitian ini adalah untuk mengetahui bagaimana akuntabilitas pengelolaan anggaran pendapatan dan belanja Desa (APBDesa) di Desa Mangkonjaya Kecamatan Bojonggambir Kabupaten Tasikmalaya. Metode dalam penelitian ini menggunakan pendekatan kualitatif penentuan informan dengan teknik purposive sampling. Teknik pengumpulan data yang dilakukan berupa observasi, wawancara dan dokumentasi dan FGD, teknik analisis data dengan reduksi data, display data serta verifikasi dan penarikan kesimpulan, dan triangulasi sumber. Hasil penelitian menunjukan bahwa untuk pembuatan pertanggungjawaban alokasi dana desa masih perlu bimbingan pihak-pihak terkait yang lebih berkompeten karena laporan pertanggungjawaban yang ada saat ini hanya berupa gambaran umum saja. kewenangan Pemerintah Desa dalam pengelolaan APBDesa ini adalah dengan mengetahui, memfasilitasi dan mengawasi. Dengan standar operasional prosedur dalam pelaporan APBDes tersebut harus dilaporkan setiap semsternya, atau enam bulan sekali. Selanjutnya dalam hal pertanggungjawaban dari Kepala Desa terhadap pengalokasian dana Desa dirasa masyarakat masih kurang karena tidak adanya keterbukaan informasi kepada mereka. Kesimpulannya akuntabilitas pengelolaan aAPBDes belum efektif..
\end{abstract}

Kata kunci: Akuntabilitas; APBDesa; Desa Mangkonjaya.

\section{Abstract}

Management accountability (APBDes) in Mangkonjaya Village still has problems including, Lack of accountability for accountability from the manager of the Village Revenue and Expenditure Budget (APBDes), namely the existence of a budget that is not issued for its purpose, Less effective and efficient in managing the Village Revenue and Expenditure Budget (APBDes), The policy for implementing the Village Revenue and Expenditure Budget (APBDes) is not appropriate for the implementation of the previous documents, namely the RKPDes and RPJMDes. The purpose of this study was to find out how the accountability of village revenue and 
expenditure budget management (APBDesa) in Mangkonjaya Village, Bojonggambir District, Tasikmalaya Regency. The method in this study uses a qualitative approach to determine informants with purposive sampling technique. Data collection techniques were carried out in the form of observation, interviews and documentation and FGD, data analysis techniques with data reduction, data display and verification and conclusion drawing, and source triangulation. The results of the study indicate that for making accountability for village fund allocations, guidance from relevant parties who are more competent is still needed because the current accountability reports are only in the form of general descriptions. The authority of the Village Government in managing the APBDesa is to know, facilitate and supervise. With standard operating procedures in the APBDes reporting, it must be reported every semester, or every six months. Furthermore, in terms of accountability from the Village Head towards the allocation of Village funds, the community feels that it is still lacking because there is no information disclosure to them. In conclusion, the accountability of the village budget management has not been effective.

\section{Keyword: Accountability; APBDesa; Mangkonjaya Village}

\section{Pendahuluan}

Pemerintahan desa merupakan lingkup terkecil dalam suatu pemerintahan Republik Indonesia. Meskipun demikian, Pemerintahan desa memiliki peranan yang cukup besar dalam pembangunan. Jika pembangunan di setiap desa dapat berjalan secara maksimal, maka tujuan dari pemerintah pusat untuk membuat pemerataan kesejahteraan dan pembangunan yang adil akan dapat terwujud. Hal ini sejalan dengan nawacita Presiden Republik Indonesia yaitu membangun Indonesia dari pinggiran, tiada lain hal ini pengembangan dan penataan pemerintah desa menjadi ujung tombak dari pembangunan Indonesia saat ini.

Lahirnya Undang-Undang No 6 tahun 2014 Tentang Desa menjelaskan bahwa desa merupakan kesatuan masyarakat hukum yang memiliki batas wilayah yang mempunyai wewenang untuk mengatur dan mengurus urusan penyelenggaraan pemerintahan, pembangunan, dan kepentingan masyarakat setempat berdasarkan prakarsa masyarakat, hak asal usul, dan/atau hak tradisional yang diakui dan dihormati dalam sistem pemerintahan Negara Kesatuan Republik Indonesia (NKRI).

Sebagaimana dijelaskan dalam Undang-Undang Nomor 6 tahun 2014 tentang Desa, bahawa pemerintah memberikan kewenangan kepada pemerintah desa untuk mengurus urusan penyelenggaraan pemerintahan, pembangunan dan kepentingan masyarakat, salah satunya dalam pengelolaan keuangan desa sebagai cermin dari proses penyelenggaran pemerintahan yang kewenangannya diberikan kepada pemerintah desa. Hal tersebut kemudian diperjelas dengan lahirnya Peraturan Menteri Dalam Negeri Nomor 113 Tahun 2014 tentang Pengelolaan Keuangan Desa. Secara jelas dalam salah satu amanah Permendagri tersebut bahwa pengelolaan keuangan desa harus dilaksanakan dalam hal perencanaan, penganggaran, pengelolaan dan pelaporan sebagai bentuk pertanggungjawaban pemerintah kepada masyarakat. Secara eksplisit sangat 
jelas bahawa dalam pelaksanaan pengelolaan keuangan desa diharuskan adanya pertanggungjawaban dari pemerintah selaku pelaksana pembangunan terhadap masyarakat, dalam rangka mewujudkan tata kelola pemerintah yang baik (good governance).

Pentingnya akuntabilitas seperti yang dikemukakan oleh (Linda, 2018). Akuntabilitas adalah keharusan lembaga-lembaga sektor publik untuk lebih menekankan pada pertanggungjawaban horizontal (masyarakat) bukan hanya pertanggungjawaban vertikal (otoritas yang lebih tinggi). Berlakunya Undang-Undang Nomor 6 tahun 2014, menuntut desa untuk lebih mandiri dalam mengelola pemerintahan dan berbagai sumber daya yang dimiliki, termasuk pengelolaan keuangan dan kekayaan milik desa. Di sinilah Badan Pengawasan Keuangan dan Pembangunan (BPKP) dan Aparat Pengawas Intern Pemerintah (APIP) sebagai auditor internal pemerintah sangat berperan dalam mengawal akuntabilitas pengelolaan dana desa.

Sistem pengelolaan keuangan desa yang dikelola oleh pemerintah desa termasuk di dalamnya mekanisme penghimpunan dan pertanggungjawaban merujuk pada Undang-undang Nomor 33 Tahun 2004 tentang Perimbangan Keuangan antara Pemerintah Pusat dan Pemerintah Daerah (Suyono \& Prakoso, 2018). Dalam aturan tersebut dijelaskan bahwa pendanaan pembangunan yang dilakukan oleh pemerintah daerah termasuk didalamnya pemerintah desa menganut prinsip money follows function yang berarti bahwa pendanaan mengikuti fungsi pemerintahan yang menjadi kewajiban dan tanggung jawab masing-masing tingkat pemerintahan.

Sejak tahun 2015, Desa mendapatkan kucuran dana sebesar 10\% dari APBN. Dana tersebut diberikan kepada pemerintah desa melalui pemerintah daerah seperti sebelumnya Alokasi Dana Desa, selanjutnya disingkat ADD, adalah dana perimbangan yang diterima Kabupaten/Kota dalam Anggaran pendapatan dan Belanja Daerah Kabupaten/Kota setelah dikurangi Dana Alokasi Khusus (Permendagri RI Nomor 113 Tahun 2014 Bab 1 Pasal 10), kemudian desa mendapatkan anggaran dari pemerintah pusat berupa Dana Desa (DD) yang diberikan untuk pelaksanaan pembangunan desa dan pemberdayaan masyarakat desa, serta desa mendapatkan bantuan lainnya untuk pelaksanaan pembangunan di desa.

Gambaran umum pembangunan tahunan yang dilaksanakan di pemerintah desa dapat tercerimin dalam dokumen Anggaran Pendapatan dan Belanja Desa (APBDes), dalam APBDes tersebut terdapat isi mengenai seluruh anggaran desa yang meliputi Pendapatan Desa, dan Belanja Desa. Sejak ditetapkannya Undang-Undang Nomor 6 tahun 2014 dan Permendagri Nomor 113 tahun 2014 membawa perubahan yang cukup baik terhadap keuangan desa.

Berkaitan dengan pengelolaan Anggaran dan Pendapatan dan Belanja Desa (APBDes), tentunya tidak lepas dari kemampuan pemerintah desa untuk mengelola APBDes sesuai kebutuhan (Mokalu, Gosal, \& Sampe, 2019). Hal ini merupakan salah satu bentuk desentralisasi guna mendorong good governance, karena mendekatkan negara kepada masyarakat dan sekaligus meningkatkan partisipasi masyarakat, yang akhirnya mendorong akuntabilitas, transparansi dan responsivitas pemerintah desa. 
Desa Mangkonjaya merupakan desa yang terletak di Kecamatan Bojonggambir yang termasuk dalam wilayah Kabupaten Tasikmalaya. Masalah umum yang dihadapi selama lima tahun terakhir adalah pendapatan dengan realisasi anggaran mengalami penurunan, hal ini menunjukan lemahnya pengelolaan keuangan Anggaran Pendapatan dan Belanja Desa (APBDes) dalam pertanggungjawaban pengelolaan keunagan desa sebagaimana dituangkan dalam Tabel 1 sebagai berikut.

Tabel 1. Realisasi APBDes Desa Mangkonjaya Tahun 2015-2018

\begin{tabular}{ccccc}
\hline No & Tahun & Pendapatan (Rp) & Realisasi (Rp) & $\begin{array}{c}\text { Persentas } \\
\text { e (\%) }\end{array}$ \\
\hline 1 & 2014 & 356.099 .069 & 360.008 .951 & Minus (-) \\
\hline 2 & 2015 & 829.184 .477 & 829.003 .813 & 99,97 \\
\hline 3 & 2016 & 1.196 .162 .151 & 1.195 .930 .700 & 99,98 \\
\hline 4 & 2017 & 1.761 .609 .990 & 1.760 .604 .362 & 99,94 \\
\hline 5 & 2018 & 1.614 .686 .859 & 1.486 .128 .229 & 92,03 \\
\hline
\end{tabular}

Sumber: Kaur Keungan Desa Mangkonjaya Tahun 2020

Jika dilihat dari tabel 1 dalam realisasi Anggaran Pendapatan dan Belanja Desa (APBDes) di Desa Mangkonjaya Kecamatan Bojonggambir, pada umumnya persentase realisasi APBDes menurun. Jika dilihat dari angka pedapatan dalam 5 (lima) tahun terakhir mengalami angka kenaikan yang cukup siginifikan, akan tetapi bebanding terbalik dengan angka realiasai dalam pencapaian pengelolaan APBDes. Jika dikaitkan dengan pertanggungjawaban pengelolaan APBDes semestinya realisasi anggaran harus terserap dengan baik. Selama 5 (lima) tahun terakhir, data menunjukan bahwa realisasi anggaran belum pernah diserap secara utuh (100\%).

Pengelolaan keuangan desa Mangkonjaya Kecamatan Bojonggambir diawali dengan perencanaan. Perencanaan diawali dengan penetapan Rencana Kerja Pemerintah Desa (RKPDes) dan Anggaran Pendapatan dan Belanja Desa (APBDes). RKPDes merupakan penjabaran dari dokumen Rencana Pembangunan Jangka Menengah Desa (RPJMDes). RPJMDes mempunyai jangka waktu enam tahun kemudian diakhiri dengan tahap pertanggungjawaban keuangan.

Tahap yang terakhir dari proses pengelolaan keuangan desa adalah pertanggungjawaban. Pertanggungjawaban Anggaran Pendapatan dan Belanja Desa (APBDes). Laporan pertanggungjawaban disampaikan kepada Bupati. Laporan pertanggungjawaban merupakan bukti atas pertanggungjawaban pemerintah desa dalam mengelola keuangan desa dan bukti bahwa pemerintah desa telah menyelesaikan program-program kegiatan yang telah direncanakan sebelumnya (Nafidah \& Anisa, 2017). Laporan pertanggungjawaban digunakan sebagai dokumen untuk menyusun anggaran di tahun berikutnya. Pertanggung jawaban Anggaran Pendapatan dan Belanja Desa (APBDes) Desa Mangkonjaya disampaikan kepada Bupati Tasikmalaya pada tanggal 31 Desember setiap tahunnya. Peran perangkat desa harus memiliki pemahaman atas peraturan perundang-undangan dan ketentuan lainnya tentang pengelolaan 
keuangan desa, serta memiliki kemampuan dan integritas untuk melaksanakan pengelolaan keuangan desa.

Kemampuan dan integritas perangkat desa sangat dibutuhkan dalam hal ini karena resiko dari pengelolaan keuangan sangatlah besar. Seperti berita yang dimuat dalam detik news Indonesia Corruption Watch (ICW) merilis sebanyak 110 kasus penyelewengan Dana Desa (DD) dan ADD sepanjang 2016 sampai dengan 10 Agustus 2017. Dari 110 kasus tersebut jumlah kerugian negara mencapai 30 (tiga puluh) milliar rupiah. Data tersebut diperoleh ICW dari berbagai sumber media hingga aparat penegak hukum. Hal tersebut menandakan bahwa pengelolaan keuangan desa sangat rawan dan berisiko terjadinya korupsi.

Membahas tentang akuntabilitas maka terdapat penelitian terdahulu yang dilakukan oleh (Lestari, 2017). Judul penelitian yang dilakukan adalah Analisis Akuntabilitas Pengelolaan Alokasi Dana Desa (ADD) (Studi Kasus di Wilayah Kecamatan Banyudono). Penelitian ini menggunakan teori (Subroto, 2009). Metode penelitian yang digunakan menggunakan metode penelitian Kualitatif-Deskriptif. Dan teknik pengumpulan datanya menggunakan Pengamatan langsung di lapangan dan wawancara. Hasil dari penelitian ini menunjukkan bahwa sistem akuntabilitas perencanaan dan pelaksanaan telah menerapkan prinsip transparansi dan akuntabilitas. Sedangkan Pertanggung jawaban Alokasi Dana Desa (ADD) baik secara teknis maupun administrasi sudah baik, namun harus tetap mendapat atau diberikan bimbingan dari pemerintah kecamatan

Adapun perbedaan penelitian terdahulu dengan penelitian ini adalah dilakukan di tempat yang berbeda serta menggunakan teori yang berbeda pula serta perbedaan dalam segi waktu serta lokus yang di gunakan kemudian hasil yang di dapat serta kesimpulan dan rekomendasi penelitian. Selanjutnya persamaannya adalah dalam sisi, variabel yang sama-sama mengangkat tema akuntabilitas, kemudian metode yang di gunakan. Tetapi ada hal menarik yang mejadi kebaharuan peneliti yaitu terletak pada penggunaan APBDes serta efektivitas penggunaannya.

Berdasarkan hal-hal yang telah dipaparkan sebelumnya, peneliti tertarik untuk meneliti lebih dalam tentang Akuntablitas Pengelolaan Anggaran Pendapatan dan Belanja Desa (APBDes) di Desa Mangkonjaya Kecamatan Bojonggambir Kabupaten Tasikmalaya. Selanjutnya berdasarkan observasi awal yang dilakukan oleh peneliti pada tahun 2019, permasalahan selanjutnya yang terjadi dalam Akuntablitas Pengelolaan Anggaran Pendapatan dan Belanja Desa (APBDes) di Desa Mangkonjaya Kecamatan Bojonggambir Kabupaten Tasikmalaya adalah sebagai berikut:

1. Kurang akuntabilitas terhadap pertanggungjawaban dari pihak pengelola Anggaran Pendapatan dan Belanja Desa (APBDes) yaitu adanya anggaran yang dikeluarkan bukan untuk peruntukannya.

2. Kurang efektif dan efesiens dalam pengelolaan Anggaran Pendapatan dan Belanja Desa (APBDes) serta banyaknya program pencapaian keu uangagan yang kurang terrealisai (antara rencana pendapatan anggaran dengan realiasasi anggaran).

3. Kebijakan pelaksanaan Anggaran Pendapatan dan Belanja Desa (APBDes) kurang tepat terhadap pelaksaan dokumen sebelumnya yaitu RKPDes dan RPJMDes. 
Berkaitan denga konsep akuntabilitas pengelolaan keuangan yang dikemukan oleh beberapa ahli dalam kajian teori, maka peneliti menyimpulkan dalam menganalisis masalah yang berada dalam latar belakang penelitian merujuk kepada pendapat ( saepudin, 2017) yang dimaksud dengan akuntabilitas dan aspek auntabilitas yaitu Akuntabilitas adalah kemampuan memberi jawaban kepada otoritas yang lebih tinggi atas tindakan seseorang/sekelompok orang terhadap masyarakat luas dalam suatu organisasi.

Adapun aspek akuntabilitas adalah:

1. Akuntabilitas Hukum dan Kejujuran (accountability for probity and legality)

Akuntabilitas hukum terkait dengan dilakukannya kepatuhan terhadap hukum dan peraturan lain yang disyaratkan dalam organisasi. Akuntabilitas hukum menjamin ditegakkannya supremasi hukum. Akuntabilitas kejujuran terkait dengan penghindaran penyalahgunaan jabatan, korupsi dan kolusi. Akuntabilitas kejujuran menjamin adanya praktik organisasi yang sehat.

2. Akuntabilitas Manajerial

Akuntabilitas manajerial dapat juga diartikan sebagai akuntabilitas kinerja (performance accountability) adalah pertanggungjawaban untuk melakukan pengelolaan organisasi secara efektif dan efesien.

3. Akuntabilitas Program

Akuntabilitas program berarti bahwa program-program organisasi hendaknya merupakan program yang bermutu dan mendukung strategi dalam pencapaian visi, misi dan tujuan organisasi.

4. Akuntabilitas Kebijakan

Lembaga-lembaga publik hendaknya dapat mempertanggungjawabkan kebijakan yang telah ditetapkan dengan mempertimbangkan dampak di masa depan.

5. Akuntabilitas Financial

Akuntabilitas financial merupakan pertanggungjawaban lembaga-lembaga publik untuk menggunakan dana publik (public money) secara ekonomis, efisien dan efektif, tidak ada pemborosan, kebocoran dana dan korupsi. Akuntabilitas financial mengharuskan lembaga-lembaga publik untuk membuat laporan keuangan yang menggambarkan kinerja financial organisasi kepada pihak luar." (Rasul dalam Saepudin, 2017), alasan penngunaan teori tersebut oleh peneliti dianggapa relevan dengan masalah yang di teliti berdasarkan observasi.

Adapun tujuan dari penelitian ini ialah untuk mengetahui bagaimana akuntabilitas pengelolaan anggaran pendapatan dan belanja desa (APBDes) di Desa Mangkonjaya Kecamatan Bojonggambir Kabupaten Tasikmalaya.

Manfaat Penelitian ini diharapkan dapat memberikan manfaat bagi berbagai pihak, bagi peneliti hasil penelitian ini diharapkan dapat menambah wawasan pengetahuan bagi peneliti tentang akuntabilitas pengelolaan (APBDesa).Secara akademik hasil penelitian ini diharapkan dapat memberi tambahan pengetahuan bagi kemajuan akademisk dan dapat dijadikan acuan atau referensi bagi penelitian selanjutnya. Bagi Instansi yang bersangkutan sebagai masukan kepada Pemerintah 
Kabupaten Tasikmalaya khususnya Desa yang di teliti dalam meningkatkan akuntabilitas pengelolaan APBDesa.

\section{Metode Penelitian}

Metode dalam penelitian ini ialah dengan menggunakan pendekatan kulaitatif dengan jenis deskriptif (Moleong, 2012). Informan dalam penelitian yang dilaksanakan di Desa Mangkonjaya Kecamatan Bojonggambir Kabupaten Tasikmalaya ialah Kepala Desa, Ketua BPD, Sekertaris Desa, Bendahara Desa dan Kasi Pemerintahan sebanyak 5 orang (Sugiyono, 2014). Teknik pengumpulan data melalui, Observasi, wawancara, dan dokumentasi. Sedangkan teknik pengolahan dan analisis datanya dmelalui data reduction/reduksi data, data display/penyajian data, data conclusion drawing/verificatio/alternatif verifikasi. Lokasi penelitian dilaksanakan di Desa Mangkonjaya Kecamatan Bojonggambir Kabupaten Tasikmalaya

\section{Hasil dan Pembahasan}

\section{Prinsip Akuntabilitas Hukum dan Kejujuran}

Akuntabilitas hukum terkait dengan dilakukannya kepatuhan terhadap hukum dan peraturan lain yang disyaratkan dalam organisasi. Akuntabilitas hukum menjamin ditegakkannya supremasi hukum. Akuntabilitas kejujuran terkait dengan penghindaran penyalahgunaan jabatan, korupsi dan kolusi. Akuntabilitas kejujuran menjamin adanya praktik organisasi yang sehat. Aspek akuntabilitas hukum dan kejujuran ini terdapat dua parameter, yakni:

\section{a) Ketaatan Pegawai Desa dalam Pengelolaan Alokasi Dana Desa}

Salah satu parameter dalam aspek akuntabilitas hukum dan kejujuran adalah ketaatan perangkat desa dalam pengelolaan Anggaran Pendapatan dan Belanja Desa (APBDes). Hal ini dapat dilihat dari pertanggungjawaban laporan hasil akhir realisasi Anggaran Pendapatan dan Belanja Desa (APBDes) setiap semesternya serta kesesuaian pelaporan Anggaran Pendapatan dan Belanja Desa (APBDes) tersebut terhadap Penggunaan Pembangunan Desa,

Berdasarkan hasil penelitian menunjukkan bahwa di dalam pelaksanaan Anggaran Pendapatan dan Belanja Desa (APBDes) senantiasa dilaporkan perkembangan pelaksanaan kegiatan oleh pengelola Anggaran Pendapatan dan Belanja Desa (APBDes) di tingkat desa, terutama tentang kegiatan fisik dan penyerapan dana yang bsersumber dari Dana Desa (DD). Dapat diketahui bahwa tanggungjawab pengelola Anggaran Pendapatan dan Belanja Desa (APBDes) di tingkat desa sudah memenuhi ketentuan pembuatan laporan kegiatan APBDes yang bertahap dan laporan akhir kegiatan. Pertanggungjawaban pelaksanaan program Anggaran Pendapatan dan Belanja Desa (APBDes) kepada pemerintah tingkat atasnya dilakukan melalui sistem pelaporan yang dilakukan secara periodik. Laporan pelaksanaan Anggaran Pendapatan dan Belanja Desa (APBDes) terdiri dari laporan pendahuluan, laporan masing-masing tahap kegiatan, laporan bulanan, dan laporan akhir kegiatan yang disusun secara komprehensip. 
Selanjutnya terkait penyampaian laporan dilaksanakan melalui jalur struktural yaitu dari Tim Pelaksana Tingkat Desa dan diketahui Kepala Desa ke Tim Pendamping Tingkat Kecamatan secara bertahap. Hal ini sesuai dengan yang dikatakan oleh Bendahara Desa Mangkonjaya berikut: "Iya, artinya setelah SPJ selesai diserahkan kepada bagian pemerintahan setelah diverifikasi oleh Tim Pendamping dari kecamatan."

Berdasarkan pemaparan diatas terlihat bahwa di dalam pelaksanaan Anggaran Pendapatan dan Belanja Desa (APBDes) senantiasa dilaporkan perkembangan pelaksanaan kegiatan oleh pegawai desa, terutama tentang kegiatan fisik dan penyerapan dana, meskipun masih diperlukan bimbingan dari pihak terkait. Hai ini karena tidak semua pegawai desa memiliki kemampuan dalam menjabarkan pengalokasian anggaran desa secara detail.

b) Kesesuaian pelaporan dan target Anggaran Pendapatan dan Belanja Desa (APBDes) terhadap Pencapaian Realisasi APBDes.

Parameter kesesuaian antara pelaporan dan target Anggaran Pendapatan dan Belanja Desa (APBDes) terhadap pencapaian program berkaitan dengan pertimbangan apakah tujuan dari program dan kegiatan yang pembiayaannya bersumber dari Anggaran Desa yang telah ditetapkan sebelumnya dapat dicapai atau tidak.

Parameter kesesuaian antara laporan dan target terhadap pencapaian program dalam akuntabilitas berkaitan dengan pertimbangan apakah tujuan yang ditetapkan dapat dicapai atau tidak. Berdasarkan pernyataan tersebut, penciptaan akuntabilitas selain ditentukan oleh hasil dari program dan kegiatan yang dilakukan, juga sangat ditentukan oleh pencapaian tujuan yang ditetapkan. Hal tersebut karena akuntabilitas adalah perwujudan kewajiban untuk mempertanggungjawabkan keberhasilan atau kegagalan atas pelaksanaan misi organisasi dalam mencapai tujuan-tujuan dan sasaran-sasaran yang telah ditetapkan melalui suatu media pertanggungjawaban secara periodik. Oleh karena itu, tujuan program dan kegiatan yang tidak dapat tercapai oleh pemerintah Desa Mangkonjaya dalam bidang pemberdayaan menunjukkan bahwa terdapat masalah yang menjadi kendala terwujudnya akuntabilitas pengelolaan Anggaran Pendapatan dan Belanja Desa (APBDes).

Berdasarkan uraian diatas, dapat disimpulkan bahwa akuntabilitas pengelolaan Dana Desa di Desa Sukraja berdasarkan parameter kesesuaian antara laporan dan target terhadap pencapaian program belum terwujud. Hal tersebut karena tujuan bidang pemberdayaan belum tercapai maksimal melalui outputya dihasilkan, meskipun tujuan di bidang pembangunan cukup dapat tercapai.

\section{Prinsip Akuntabilitas Manajerial}

Akuntabilitas manajerial dapat juga diartikan sebagai akuntabilitas kinerja (performance accountability) yakni pertanggungjawaban untuk melakukan pengelolaan organisasi secara efektif dan efesien. Prosedur dalam penggunaan Anggaran Pendapatan dan Belanja Desa (APBDes), dalam parameter ini peneliti menentukan dua parameter yakni: 
a) Sistem Informasi Yang Jelas dan Terbuka Terhadap Masyarakat

Aspek-aspek dalam akuntabilitas manjerial ini antara lain sistem informasi yang jelas dan terbuka terhadap masyarakat tentang Anggaran Pendapatan dan Belanja Desa (APBDes) serta kelengkapan prosedur administrasi dalam Anggaran Pendapatan dan Belanja Desa (APBDes) terkait keuangan desa, sumber keuangan desa, dan anggaran pendapatan dan belanja desa.

Berdasarkan hasil penelitian, maka dapat diketahui bahwa Pemerintah Desa tidak terbuka terhadap masyarakat Desa, yang berarti dalam hal ini pertanggungjawaban terhadap masyarakatnya dapat dipertanyakan karena seharusnya pelaksanaan pengelolaan Anggaran Pendapatan dan Belanja Desa (APBDes) dilaksanakan secara partisipatif bersama masyarakat, sehingga masyarakat tahu tentang APBDes. Sebagaimana tercantum dalam Peraturan Menteri Dalam Negeri tentang Pengelolaan Keuangan Desa BAB II Pasal 2 yang menyebutkan bahwa : "Keuangan desa dikelola berdasarkan asas-asas tranparan, akuntabel, partisipatif serta dilakukan dengan tertib dan disiplin anggaran."

\section{b) Kelengkapan Prosedur Administrasi dalam APBDes}

Terkait prosedur administrasi dalam pengelolaan Anggaran Pendapatan dan Belanja Desa (APBDes) ini, pemahaman tentang pengelolaan administrasi keuangan APBDes dapat diketahui dari hasil wawancara dengan beberapa informan menjelaskan sebagai berikut: "Pertamanya dicatat di buku kas pembantu umum dengan dilengkapi dengan bukti-bukti pendukung yang sah dan dapat dipertanggungjawabkan. Yang penerima jika berbentuk bantuan sosial, juga dimintakan surat kepenerimaan dan nota-nota yang sah."

Berdasarkan hasil penelitian, dapat disimpulkan bahwa akuntabilitas pengelolaan Dana Desa di Desa Mangkonjaya berdasarkan parameter kepatuhan terhadap prosedur telah terwujud. Hal tersebut karena seluruh rangkaian prosedur atau tahapan pengelolaan Dana Desa oleh pemerintah Desa Mangkonjaya taat dan sesuai dengan Peraturan Menteri Dalam Negeri Nomor 113 Tahun 2014 tentang Pedoman Pengelolaan Keuangan Desa.

\section{Prinsip Akuntabilitas Program}

Akuntabilitas program berarti bahwa program-program organisasi hendaknya merupakan program yang bermutu dan mendukung strategi dalam pencapaian visi, misi dan tujuan organisasi. Dalam akuntabilitas program ini memperhatikan ketercapaian program alokasi dana desa, mutu/kualitas pelaporan alokasi dana desa, mutu/kualitas penggunaan alokasi dana desa, serta ketepatan strategi dalam pengelolaan alokasi dana desa.

\section{a) Ketercapaian Program APBDesa}

Tingkat akuntabilitas dalam implementasi pengelolaan Anggaran Pendapatan

dan Belanja Desa (APBDes) dimulai dari perencanaan, pelaksanaan, dan pertanggungjawaban, dengan demikian akan didukung pula penerapan prinsip transparan, akuntabel dan responsif. Oleh karena itu untuk mengetahui secara lebih jelas, implementasi prinsip-prinsip tersebut perlu diketahui mulai dari perencanaan, 
mekanisme penentuan arah penggunaan dana, pelaksanaan dan sistem pertanggungjawaban dan pengawasan Anggaran Pendapatan dan Belanja Desa (APBDes) secara lengkapm adapun hasil konfirmasi kepada Kepala Desa Mangkonjaya menyatakan bahwa mengenai ketercapaian program dalam penggunaan Alokasi Dana Desa sudah 80 \% tercapai. dengan kualitas tim pengelola Anggaran desa terdiri dari Tim Pelaksana Kegaitan (TPK) dan Para Kasi”. Sementara Sekertaris Desa Mangkonjaya menyebutkan bahwa

"Penggunaan Alokasi Dana Desa saat ini memang lebih besar dalam bidang Penyelenggaraan Pemerintahan Desa sebanyak Rp.351.358.000,-. ADD tersebut sejauh ini digunakan untuk kesejahteraan perangkat desa dan kepala desa juga lembaga desa seperti LPM, BPD, RT dan RW".

Berikut ini adalah data penggunaan alokasi dana desa tahun 2019-2020

Tabel 2. Penggunaan Alokasi Dana Desa Tahun 2019-2020

\begin{tabular}{llr}
\hline No & \multicolumn{1}{c}{ Penggunaan Alokasi Dana Desa } & \multicolumn{1}{c}{ Jumlah } \\
\hline 1 & Bidang Penyelenggaraan Pemerintahan Desa & 351.358 .000 \\
\hline 2 & Bidang Pembinaan Kemasyarakatan & 35.636 .000 \\
\hline 3 & Bidang Pemberdayaan Masyarakat & 9.400 .000 \\
\hline 4 & Bidang Pembangunan Desa & 14.261 .287 \\
\hline & Jumlah & 410.655 .287 \\
\hline
\end{tabular}

Sumber: Kaur Keuangan Desa Mangkonjaya Tahun 2020

Berdasarkan hasil penelitian dan temuan yang didapat peneliti tersebut menunjukkan bahwa ketercapaian program dalam penggunaan Alokasi Dana Desa sudah cukup tercapai dengan kualitas tim pengelola Alokasi Dana Desa juga maksimal. Hanya saja belum ada alokasi di bidang kepemudaan belum diakomdir dengan baik.

b) Evaluasi Efektivitas Pelaksanaan Kebijakan Anggaran terhadap Program yang Dilaksanakan

Perlunya melaksanakan sebuah kebijakan dan program secara efektif ialah agar tujuan dan sasaran yang telah ditetapkan dari kebijakan tersebut dapat tercapai. Begitu juga pada kebijakan Anggaran Pendapatan dan Belanja Desa (APBDes), yang bertujuan untuk meningkatkan kinerja Pemerintahan Desa dalam melaksanakan kegiatan pemerintahan, pelaksanaan, pembangunan, pelayanan masyarakat dan pemberdayaan masyarakat sesuai kewenanganpemerintahan desa sendiri. Dalam penelitian ini, hasil wawancara dengan Kepala Desa Mangkonjaya menyebutkan untuk bisa mengukur efektivitas pelaksanaan kebijakan Anggaran Pendapatan dan Belanja Desa (APBDes) terhadap semua programnya yaitu dengan menggunakan kinerja implementasi.

Evaluasi efektivitas pelaksanaan kebijakan APBDes terhadap program yang dilaksanakan yang pertama dapat terlihat dari akses. Akses digunakan untuk mengetahui bahwa kebijakan atau pelayanan yang diberikan mudah dijangkau oleh kelompok sasaran. Selain itu akses juga mengandung pengertian bahwa orang-orang 
yang bertanggungjawab untuk mengimplementasikan kebijakan atau program mudah dikontak oleh masyarakat yang menjadi kelompok sasaran kebijakan atau program tersebut apabila mereka membutuhkan informasi atau ingin menyampaikan pengaduan.

Berdasarkan hasil penelitian menunjukkan bahwa efektivitas pelaksanaan kebijakan Anggaran Pendapatan dan Belanja Desa (APBDes) terhadap semua program dari segi akses yang diterima oleh pemerintah Desa Mangkonjaya untuk memanfaatkan dana baik ADD, DD Bantuan keuangan dari pemerintah Kabupaten Tasikmalaya cukup mudah serta dalam pelaksanaan kebijakan Anggaran Pendapatan dan Belanja Desa (APBDes) sendiri tidak pernah terlambat, dikarenakan dari pihak pemerintah Desa Mangkonjaya selalu tepat waktu dalam mengumpulkan SPJ di setiap triwulan.

\section{Prinsip Akuntabilitas Kebijakan}

Akuntabilitas kebijakan disini berarti lembaga-lembaga publik hendaknya dapat mempertanggungjawabkan kebijakan yang telah ditetapkan dengan mempertimbangkan dampak di masa depan, dari aspek tersebut, peneliti menjabarkan kedalam dua parameter yaitu:

\section{a) Adanya Pertanggungjawaban yang Jelas dari Kepala Desa}

Berdasarkan hasil wawancara, dalam hal pertanggungjawaban dari Kepala Desa terhadap pengalokasian dana desa dirasa masyarakat masih kurang karena tidak adanya keterbukaan informasi kepada mereka. Sehingga mau tidak mau memunculkan dua kubu di masyarakat. Satu kubu, menyerahkan semuanya ke Pemerintah Desa, kubu yang lainnya meminta agar mereka diikut sertakan sehingga dapat mengawal langsung pengalokasian ADD tersebut.

Namun pemerintah desa berdalih seperti yang dijelaskan oleh Kepala Desa memberikan penjelasan sebagai berikut: "Ada kok keterbukaan sesuai apa yang sudah dilaksanakan oleh petugas yang memang ditugaskan. Dalam hal ini petugasan dalam melakukan kegiatan yaitu Timlak (Tim Pelaksana) sesuai dengan anggaran dan pelaksanaan yang ada."

Berdasarkan hasil penelitian menunjukkan bahwa pertanggung jawaban yang jelas dari Kepala Desa terhadap penerapan prinsip transparansi di dalam perencanaan Anggaran Pendapatan dan Belanja Desa (APBDes) tidak dapat diketahui oleh seluruh masyarakat desa karena pelaksanaan kegiatan-kegiatan yang pembiayaannya bersumber dari Anggaran Pendapatan dan Belanja Desa (APBDes) sepenuhnya dilaksanakan oleh Tim Pelaksanaan Desa.

\section{b) Adanya Pertanggungjawaban Laporan terhadap Masyarakat}

Parameter ini digunakan untuk menilai apakah tindakan para implementer dalam menjalankan tugas mereka untuk menyampaikan keluaran kebijakan kepada kelompok sasaran dapat dipertanggungjawabkan atau tidak. Pertanyaan-pertanyaan penting yang perlu diajukan adalah menyangkut apakah hak-hak kelompok sasaran dikurangi atau tidak. Jika ada pengurangan hak-hak kelompok sasaran apakah 
tindakan tersebut dapat dipertanggungjawabkan atau merupakan bentuk-bentuk penyimpangan.

Dalam penyampaian pertanggungjawaban pelaksanaan kebijakan yang dilakukan oleh Pemerintah Desa Mangkonjaya kepada Pemerintah Kabupaten Tasikmalaya khususnya pada pelaksanaan ini tidak ditemukan permasalahan, karena apabila ada masalah tentunya juga akan menghambat turunnya dana pada waktu selanjutnya. Berbeda dengan pertanggungjawaban terhadap pemerintah Kabupaten Tasikmalaya, pertanggungjawaban pemerintah Desa Mangkonjaya kepada masyarakatnya berbanding terbalik. Dalam pelaporan pertanggungjawaban pada tiap kegiatan, tidak semua masyarakat diundang dan tahu terkait penggunaan anggaran Alokasi Dana Desa (ADD) untuk apa saja. Diperparah lagi, dalam pemaparan SPJ tidak ada rapat evaluasi terhadap pelaksanaan kebijakan di Desa Mangkonjaya dan sudah berbentuk form yang tinggal ditandatangani oleh perwakilan masyarakat Desa Mangkonjaya yang mengikuti Musrenbangdes.

Transparansi yang dilakukan oleh pemerintah Desa Mangkonjaya dianggap masih kurang bahkan dicurigai oleh beberapa elemen masyarakat yang beranggapan bahwasannya penggunaan dana ADD tidak sesuai antara laporan dengan realisasinya di lapangan. Hal itu juga dikarenakan tidak adanya kontrol dari pihak masyarakat Desa Mangkonjaya sendiri sebagai bentuk kewajiban masyarakat seperti yang tercantum dalam Undang-undang Nomor 6 Tahun 2014 pasal 68 ayat 2 tentang kewajiban masyarakat dalam mendorong penyelenggaraan pemerintahan yang baik.

Berdasarkan hasil penelitian dan temuan tersebut menunjukkan bahwa pertanggungjawaban pemerintah Desa Mangkonjaya kepada masyarakatnya berbanding terbalik dengan pertanggung jawaban kepada Kabupaten. Dimana dalam pelaporan pertanggungjawaban pada tiap kegiatan, tidak semua masyarakat diundang dan tahu terkait penggunaan anggaran Anggaran Pendapatan dan Belanja Desa (APBDes) untuk apa saja.

\section{Akuntabilitas Financial}

Akuntabilitas financial merupakan pertanggungjawaban lembaga-lembaga publik untuk menggunakan dana publik (public money) secara ekonomis, efisien dan efektif, tidak ada pemborosan, kebocoran dana dan korupsi. Akuntabilitas financial mengharuskan lembaga-lembaga publik untuk membuat laporan keuangan yang menggambarkan kinerja financial organisasi kepada pihak luar. Dari indikator tersebut, peneliti menetpkan dua parameter yakni:

\section{a) Efisiensi dan Efektivitas dalam Pelaporan APBDes}

Dalam akuntabiitas financial, dapat dilihat dari efisiensi dan efektivitas dalam Pelaporan Alokasi Dana Desa, serta efisiensi dan efektivitas dalam Penggunaan Anggaran Pendapatan dan Belanja Desa (APBDes). Untuk melihat akuntabilitas efisiensi dan efektivitas pemerintah desa Mangkonjaya dalam pengelolaan APBDes dapat terlihat dari tahapan berikut yang terdiri dari: perencanaan, pelaksanaan, dan pelaporan. 
Berdasarkan hasil penelitian dan temuan tersebut menunjukkan bahwa akuntabilitas efisiensi dan efektivitas pemerintah desa Mangkonjaya dalam pengelolaan Anggaran Pendapatan dan Belanja Desa (APBDes) dapat terlihat dari: perencanaan, pelaksanaan, dan pelaporan. Dimana mekanisme tahap perenanaan pada pengelolaan APBDes di Desa Mangkonjaya berawal dari pelaksanaan musyawarah desa, dengan pengelola terkait dengan APBDes ini dikelola oleh tim pelaksana atau PTPKD (Pelaksana Teknis Pengelolaan Keuangan Desa) dan Bendahara yang diketuai oleh Kepala Desa sendiri serta sistem pelaporannya dilakukan melalui dua bentuk yakni secara subtantif dan normatif.

\section{b) Efisiensi dan efektivitas dalam Penggunaan Alokasi Dana Desa}

Efektivitas organisasi dapat diukur dari Kejelasan tujuan yang hendak dicapai yang mana hal ini merupakan aspek yang paling mendasar yang harus diperhatikan dalam pelaksanaan penggunaan Anggaran Pendapatan dan Belanja Desa (APBDes). Tujuan yang ingin dicapai, hendaklah memperhatikan pedoman dari pengelolaan APBDes yang dimulai dari tahap perencanaan dan pelaksanaan dalam upaya pencapaian tujuan dari pengelolaan APBDes.

Berdasarkan hasil penelitian dan temuan peneliti menunjukkan bahwa efisiensi dan efektivitas dalam penggunaan alokasi dana desa, dalam pelaksanaan Anggaran Pendapatan dan Belanja Desa (APBDes) tersebut strategi pemerintah desa dilakukan dari selama 6 tahun yang disusun didalam Rencana Pembangunan Jangka Menengah (RPJMDesa). Adapun program pemerintah desa yang dijalankan belum dikatakan berhasil pkarena rogram-program yang sudah dijalankan oleh pemerintah desa pada tahun 2019 yang benar-benar selesai hanya beberapa kegiatan yang dilaksanakan seperti perbaikan jalan.

\section{Kesimpulan}

Berdasarkan hasil penelitian penulis terkait akuntabilitas pengelolaan Anggaran Pendapatan dan Belanja Desa (APBDes) di Desa Mangkonjaya Kecamatan Bojonggambir Kabupaten Tasikmalaya, maka dapat disimpulkan bahwa:

\section{Akuntabilitas Hukum dan Kejujuran}

Dalam pelaksanaan Anggaran Pendapatan dan Belanja Desa (APBDes) senantiasa dilaporkan perkembangan pelaksanaan kegiatan oleh perangkat desa, terutama tentang kegiatan fisik dan penyerapan dana. Akuntabilitas pengelolaan Anggaran Pendapatan dan Belanja Desa (APBDes) berdasarkan parameter kesesuaian antara laporan dan target terhadap pencapaian program belum terwujud.

\section{Akuntabilitas Manajerial}

Pemerintah Desa tidak terbuka terhadap masyarakat Desa, dalam hal pertanggungjawaban terhadap masyarakatnya dapat dipertanyakan karena seharusnya pelaksanaan pengelolaan Anggaran Pendapatan dan Belanja Desa (APBDes) dilaksanakan secara partisipatif bersama masyarakat. Akuntabilitas pengelolaan Alokasi Dana Desa (ADD) dan Dana Desa di Desa Mangkonjaya berdasarkan parameter kepatuhan terhadap prosedur telah terwujud. 


\section{Akuntabilitas Program}

Ketercapaian program dalam penggunaan Alokasi Dana Desa sudah cukup tercapai dengan kualitas tim pengelola Alokasi Dana Desa juga maksimal. Hanya saja belum ada alokasi di bidang kepemudaan. Efektivitas pelaksanaan kebijakan Alokasi Dana Desa (ADD) terhadap semua program, dari segi akses yang diterima oleh pemerintah Desa Mangkonjaya untuk memanfaatkan dana Alokasi Dana Desa (ADD) dari pemerintah Kabupaten Tasikmalaya cukup mudah.

\section{Akuntabilitas Kebijakan}

Pertanggung jawaban yang jelas dari Kepala Desa terhadap penerapan prinsip transparansi di dalam perencanaan ADD tidak dapat diketahui oleh seluruh masyarakat. Pertanggungjawaban pemerintah Desa Mangkonjaya kepada masyarakatnya berbanding terbalik dengan pertanggung jawaban kepada Kabupaten.

\section{Akuntabilitas Financial}

Akuntabilitas efisiensi dan efektivitas pemerintah Desa Mangkonjaya dalam pengelolaan ADD dapat terlihat dari: perencanaan, pelaksanaan, dan pelaporan. Mekanisme tahap perenanaan pada pengelolaan ADD di Desa Mangkonjaya, ADD ini dikelola oleh tim pelaksana atau PTPKD (Pelaksana Teknis Pengelolaan Keuangan Desa). Efisiensi dan efektivitas dalam penggunaan alokasi dana desa, dalam pelaksanaan ADD tersebut strategi pemerintah desa dilakukan dari selama 6 tahun yang disusun didalam Rencana Pembangunan Jangka Menengah (RPJMdesa). Adapun program pemerintah desa yang dijalankan belum dikatakan berhasil karena rogram-program yang sudah dijalankan oleh pemerintah desa pada tahun 2018-2019 yang benar-benar selesai hanya beberapa kegiatan yang dilaksanakan sepertii perbaikan jalan, semenisasi jalan, serta pembuatan balai makam 
Akuntabilitas Pengelolaan Anggaran Pendapatan dan Belanja Desa (Apbdes) di Desa Mangkonjaya Kecamatan Bojonggambir Kabupaten Tasikmalaya

\section{Bibliografi}

Iyef, Saepudin dan. (2017). Akuntabilitas Pengelolaan Alokasi Dana Desa Di Desa Cintaraja Kecamatan Singaparna Kabupaten Tasikmalaya Tahun 2017 (Kybernolog). Tasikmalaya.

Lestari, Sri. (2017). Analisis Akuntabilitas Pengelolaan Alokasi Dana Desa (ADD). Skripsi, Jurusan Akuntasi Syariah Fakultas Ekonomi dan Bisnis Islam Institut

Linda, Ma'arif Ari Varida. (2018). Pengaruh Penyajian Laporan Keuangan Daerah Dan Aksesibilitas Laporan Keuangan Daerah Terhadap Transparansi Dan Akuntabilitas Pengelolaan Keuangan Daerah Pada Dinas Dan Badan Di Kabupaten PonorogO. Universitas Muhammadiyah Ponorogo.

Mokalu, Ersi Erlita, Gosal, Ronny, \& Sampe, Stefanus. (2019). Transparansi Dan Akuntabilitas Pengelolaan Anggaran Pendapatan Dan Belanja Desa Sinsingon Kecamatan Passi Timur Kabupaten Bolaang Mongondow. JURNAL EKSEKUTIF, $3(3)$.

Moleong, Lexy J. (2012). Metodologi Penelitian Kualitatif, Bandung. Pariwisata Pedesaan Sebagai Alternatif Pembangunan Berkelanjutan (Laporan Penelitian Hibah Bersaing Perguruan Tinggi) Yogyakarta.

Nafidah, Lina Nasehatun, \& Anisa, Nur. (2017). Akuntabilitas pengelolaan keuangan desa di kabupaten Jombang. Jurnal Ilmu Akuntansi, 10(2), 273-288. $\underline{10.15408 / \text { akt.v10i2.5936 }}$

Rasul, Syahruddin. (2002). Pengintegrasian Sistem Akuntabilitas Kinerja dan Anggaran. Jakarta: Detail Rekod.

Subroto, Agus. (2009). Akuntabilitas pengelolaan dana desa (studi kasus pengelolaan alokasi dana desa di desa-desa dalam wilayah Kecamatan Tlogomulyo Kabupaten Temanggung Tahun 2008). UNIVERSITAS DIPONEGORO.

Sugiyono, Metode. (2014). Penelitian Pendidikan Pendekatan Kuantitatif Kualitatif R\&D cet. Ke-19, Bandung: Alfabeta.

Suyono, Djoko, \& Prakoso, Fajar Eko Agung. (2018). Implementasi Program Sistem Keuangan Desa (SISKEUDES) dalam Pengelolaan Keuangan Desa di Desa Slawi Kulon Kecamatan Slawi Kabupaten Tegal Tahun 2017. Indonesian Governance Journal: Kajian Politik-Pemerintahan, 1(1). https://doi.org/10.24905/pgj.v1i1.1214

Peraturan Menteri Dalam Negeri Nomor 113 Tahun 2014 tentang Pedoman Pengelolaan Keuangan Desa.

Peraturan Menteri Dalam Negeri Nomor 113 Tahun 2014 tentang Pengelolaan $\underline{\text { Keuangan Desa }}$ 
Deni Nurcahya

Undang-undang Nomor 33 Tahun 2004 tentang Perimbangan Keuangan antara Pemerintah Pusat dan Pemerintah Daerah.

Undang-Undang No 6 tahun 2014 Tentang Pemerintahan Desa 